\title{
PHYSICAL DEPENDENCE ON NITROUS OXIDE IN MICE: RESEMBLANCE TO ALCOHOL BUT NOT TO OPIATE WITHDRAWAL
}

\author{
Brian Milne, Frank W. Cervenko and Khem H. Jhamandas
}

\begin{abstract}
Mice of two strains, Crl:CD-I(ICR)Br and C57BL6, were exposed to nitrous oxide at concentrations of 50,65 and 80 per cent for 34 or 68 hours. Cessation of nitrous oxide resulted in characteristic convulsions similar to those seen in alcohol withdrawal in all mice. These peaked in severity within 2-3 minutes after removal from nitrous oxide and declined over 6 hours. The severity and duration of these convulsions were related to the nitrous oxide concentration and duration of exposure. Naloxone or naltrexone produced no significant increase in severity of convulsions. The narcotic antagonists did not precipitate acute weight loss or characteristic jumping behaviour seen in animals dependent on opiates. These results demonstrate that chronic exposure to nitrous oxide results in development of physical dependence which resembles alcohol and not opiate dependence. Analgesia and physical dependence produced by nitrous oxide appear to be mediated through separate mechanisms.
\end{abstract}

Key Words: Anaesthesia: Dependence, Nitrous Oxide, Mice; Convulsions, Alcohol, Naloxone, Naltrexone.

RECENT STUDIES ${ }^{1-3}$ have proposed that the opiate-like action of nitrous oxide may be due to its release of endogenous opiates. Evidence in favour of nitrous oxide being a morphine-like substance includes its analgesic and euphoric properties, abuse potential ${ }^{4}$ and the reversal of its effects on pain, ${ }^{2,3}$ locomotor activity, ${ }^{5}$ and cerebral evoked potentials ${ }^{6}$ by the narcotic antagonist naloxone. In addition, tolerance to nitrous oxide $^{1.7 .8}$ and cross tolerance between nitrous oxide and morphine have been reported. Mice manifest characteristic convulsions after exposure to nitrous oxide ${ }^{9,10}$ and other anaesthetics including ethylene, cyclopropane and diethyl ether. "These convulsions are similar to those seen in the withdrawal syndrome observed in mice after inhalation of ethanol vapour. ${ }^{12}$ If nitrous oxide acts by releasing endogenous opiates, then mice exposed to nitrous oxide should exhibit

Brian Milne, M.D., Resident, Department of Anaesthesia; Frank W. Cervenko, M.D., F.R.C.P.(C), Associate Professor, Department of Anaesthesia; Khem H. Jhamandas, Ph.D., Associate Professor, Department of Pharmacology; Queen's University, Kingston, Ontario, Canada.

Correspondence and reprint requests to: Dr. F. Cervenko, Department of Anaesthesia, Queen's University, Kingston General Hospital, Kingston, Ontario, Canada, K7L 2V7.

Supported by the Medical Research Council of Canada. Presented at the Canadian Anaesthetists' Society Annual Meeting, Toronto, June 1980. opiate-like withdrawal since chronic exposure to such opiates (methionine enkephalin and $\beta$ endorphin) results in physical dependence. ${ }^{13}$ The objective of this study was to characterize the withdrawal syndrome in mice chronically exposed to nitrous oxide, and to determine whether such animals exhibit physical dependence of the opiate type. As the withdrawal syndrome precipitated by naloxone is regarded as an indicator of physical dependence on opiates, we have evaluated the action of naloxone and naltrexone on nitrous oxide dependent mice.

\section{MeTHODS}

Experiments were carried out using two strains of male mice (25-30 gms) obtained from Canadian Breeding Farm and Laboratories Ltd., St. Constant, Quebec. Seven groups of 30 Swiss White CrL:CD-1(ICR)Br mice were exposed to nitrous oxide and oxygen with the inhaled nitrous oxide concentration being 80 per cent (three groups), 65 per cent (two groups), 50 per cent (one group) and in increasing concentrations from 40-80 per cent (one group). One group of 30 , C57BL6, mice was exposed to nitrous oxide (80 per cent) and oxygen (20 per cent). A control group of 30 Swiss White mice was exposed to air. Exposure, using a 12 hour light/dark cycle, lasted 68 hours in all experiments except one (Swiss White, nitrous oxide, 65 per cent) which lasted 34 
hours. The nitrous oxide, oxygen mixture was delivered from compressed gas cylinders through anaesthetic flow meters and a humidifier to an airtight plexiglass cage $(52 \times 34 \times 30 \mathrm{~cm})$ where the animals were housed. Mice were given full access to food and water inside the cage. In the control experiment, air was delivered from a compressed gas wall outlet to the humidifier. There was a separate recirculation circuit in the cage which moved gas by a push-pull fan through a carbon dioxide absorber. Oxygen concentration was measured continuously using an Harlake oxygen analyzer. A separate fan at the top of the cage aided in mixing the gases. Flow rates were $10 \mathrm{1} / \mathrm{min}$ for the first 20 minutes, then $2.5 \mathrm{1} / \mathrm{min}$ for the balance of the experiment.

After exposure, mice were divided into three groups of 10 , with control groups receiving intraperitoneal injections of $0.2 \mathrm{ml}$ normal saline. The other groups of 10 received either naloxone $2.5,5.0,10$ or $20 \mathrm{mg} \cdot \mathrm{kg}^{-1}$ or naltrexone 10 or $20 \mathrm{mg} \cdot \mathrm{kg}^{-1}$ in $0.2 \mathrm{ml}$ saline intraperitoneally.

Assessment of nitrous oxide withdrawal in mice was made by observation of their general behaviour and grading of convulsions, weight loss, and jumping activity at 15 minutes, 2, 4 and 6 hours after removal from the cage. Convulsions were also assessed immediately after exposure. Injection of the narcotic antagonist or saline was administered five minutes before each assessment. The convulsion syndrome included a characteristic tonic or clonic convulsion elicited by lifting the mouse by the tail. In alcohol withdrawal, this is a reliable and reproducible measure of the severity of the overall syndrome. ${ }^{14}$ The convulsions were rated independently by two observers using a scale of $1-4$ as described by Goldstein. ${ }^{14}$

Mice physically dependent on morphine manifest an antagonist-precipitated withdrawal by an uncontrollable urge to jump, which is used to predict physical dependence on narcotic analgesics. ${ }^{15}$ Jumping was assessed by placing a group of five animals on a circular platform, $35 \mathrm{~cm}$ in diameter and $70 \mathrm{~cm}$ high and recording the total number of jumps off the table in a 15 minute period. ${ }^{16}$ Weight loss was measured over the period of exposure to nitrous oxide and during the six hour withdrawal period.

Statistical analysis comparing the concentration and duration of nitrous oxide exposure to the convulsion severity, and comparison of the convulsion severity in the two strains of mice was determined using the unpaired Student's t-test, two-tailed, and significance was assessed when

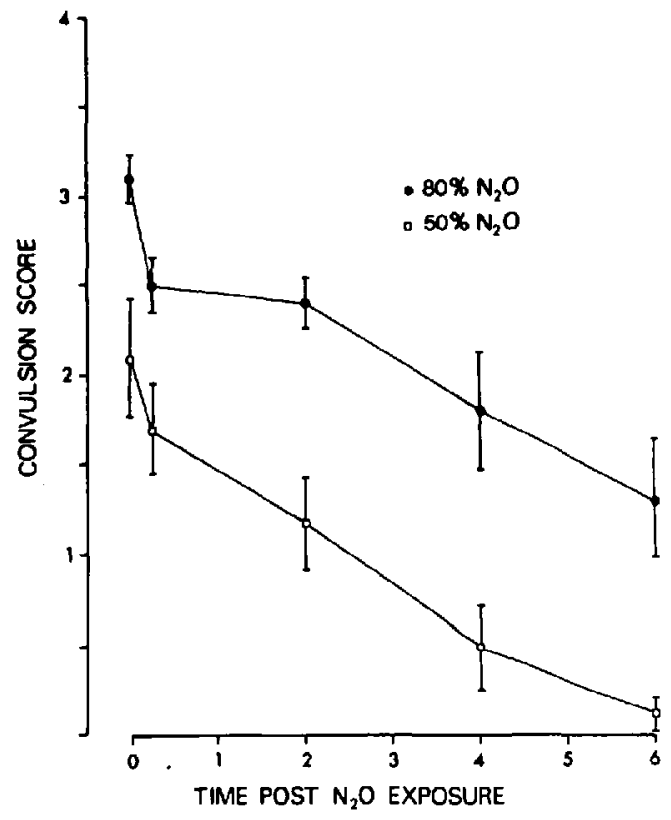

FIGURE 1 Relationship between nitrous oxide $\left(\mathrm{N}_{2} \mathrm{O}\right)$ concentration and withdrawal convulsions over six hours.

the $p$ value was less than 0.05 . Analysis of variance was used to assess significance at the $F \propto$ 0.05 level in determining the effect of the narcotic antagonists on convulsion severity (two-way) and on weight loss and jumping behaviour (oneway).

\section{RESULTS}

Introduction of nitrous oxide into the cage resulted in mice showing increased locomotor activity. However, for the duration of the exposure, most animals went to sleep; but a few demonstrated intermittent hyperactivity, such as running in circles and rapid grooming. Weight loss in Swiss White mice was 12,10 and 4 per cent of the initial weight during exposure to 80 per cent $(68$ hours), 65 per cent ( 68 hours) and 65 per cent ( 34 hours) nitrous oxide respectively, while the control group gained two per cent.

After removal from the cage, mice immediately showed the characteristic handling convulsions. In addition we noted tail flicking, tremors, and lack of exploratory activity, with a few animals exhibiting straub tail effect (a characteristic response to opiate administration in rodents). Diarrhoea, increased urination or sniffing were not observed. Convulsions were at their peak immediately after removal of animals from the 
TABLE I

EfFEct of Naloxone and Naltrexone ON Weight Loss* and JUMPING** in $\mathrm{N}_{2} \mathrm{O}(80 \%)$ Dependent Swiss White Mice

\begin{tabular}{lccc}
\hline \multicolumn{1}{c}{ Antagonist } & Dose $\left(\mathrm{mg} \cdot \mathrm{kg}^{-1}\right)$ & Weight Loss (gm) & Jumping \\
\hline Saline (control) & $0.2 \mathrm{ml}$ & $1.34 \pm 0.66$ (S.E.) & 1 \\
Naloxone & 2.5 & $1.21 \pm 0.59$ & 0 \\
& 5.0 & $1.13 \pm 0.74$ & 0 \\
& 10 & $2.19 \pm 0.69$ & 1 \\
Naltrexone & 20 & $0.93 \pm 0.40$ & 0 \\
& 10 & $0.90 \pm 0.66$ & 0 \\
& 20 & $0.53 \pm 0.38$ & 3 \\
\hline
\end{tabular}

*Weight loss by animals during six hour period following withdrawal from nitrous oxide.

**Number of jumps in 15 minute period (see Methods).

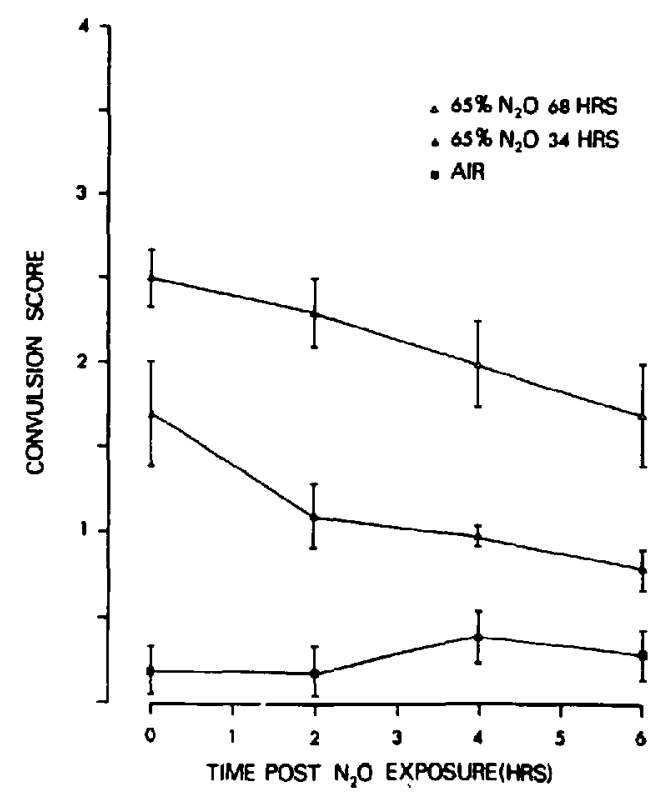

FIgURE 2 Relationship between duration of nitrous oxide $\left(\mathrm{N}_{2} \mathrm{O}\right)$ exposure and withdrawal convulsions.

chamber and declined rapidly in severity over the six hour observation period (Figure 1).

The severity of withdrawal convulsions, as indicated by peak scores, was directly dependent on both the concentration of inspired nitrous oxide (Figure 1) and the time of exposure to the gas (Figure 2). Peak scores of $3.1 \pm 0.13$ (S.E.) and $2.1 \pm 0.38$ were obtained in Swiss White mice exposed to 80 per cent and 50 per cent nitrous oxide respectively. Animals exposed to $65 \mathrm{per}$ cent nitrous oxide for 68 hours showed a peak score of $2.5 \pm 0.17$ while those exposed to the same concentration for 34 hours showed a score of $1.7 \pm 0.30$. These differences between peak scores were statistically significant $(p<0.035)$.
Figure 3 shows the effect of naloxone 2.5 and $5 \mathrm{mg} \cdot \mathrm{kg}^{-1}$ on convulsion scores after nitrous oxide 80 per cent. Analysis of variance showed that the narcotic antagonists, at these and at higher doses, had no significant $(F \propto 0.05)$ effect on the severity or the time course of convulsions. Naloxone and naltrexone, in the doses utilized, did not precipitate significant $(F \propto 0.05)$ jumping activity (Table I). A few mice exposed to 80 per cent nitrous oxide were treated with doses up to $100 \mathrm{mg} \cdot \mathrm{kg}^{-1}$ but failed to exhibit jumping behaviour. In addition, weight loss by the animals during the six hour period after nitrous oxide

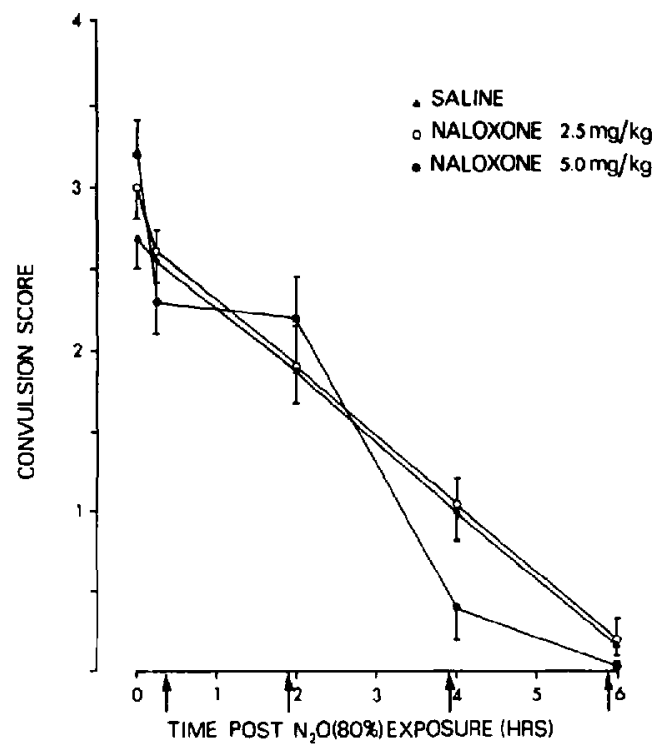

Figure 3 Effect of naloxone treatment on nitrous oxide $\left(\mathrm{N}_{2} \mathrm{O}\right)$ withdrawal convulsions. Naloxone or saline were administered intraperitoneally at points indicated by arrows. 
exposure was not significantly $(\mathrm{F} \propto 0.05)$ affected by the narcotic antagonists (Table I). Increasing the nitrous oxide concentration in one group of mice from 40 to 80 per cent over the 68 hour exposure, which more closely simulates the pattern of ascending dose in narcotic dependence studies, had no significant $(\mathrm{p}>0.05$ ) effect on jumping activity or weight loss.

The C57BL6 mice were noted to be more hyperactive before exposure to nitrous oxide; however, no significant increase in jumping activity, weight loss or convulsion severity occurred after injection of naloxone or naltrexone. After exposure to nitrous oxide 80 percent the peak severity of withdrawal convulsions in the C57BL6 group $(1.1 \pm 0.31)$ was significantly lower when compared with the Swiss White, CD-1, group $(3.1 \pm 0.13)(P<0.05)$

\section{Discussion}

This study shows that the severity and the duration of nitrous oxide withdrawal convulsions is related to both the concentration and duration of nitrous oxide exposure in mice. The convulsions observed here resemble closely the ethanol withdrawal seizures described by Goldstein in mice exposed to ethanol vapour. ${ }^{12}$ The nitrous oxide convulsions were at their peak 2-3 minutes after removal of the animals from the gas and thereafter declined very rapidly over the six hour observation period. By contrast, alcohol withdrawal seizures, although related in severity to the duration of exposure to this agent, peak 6-8 hours following its withdrawal. This difference might be partly related to the faster clearance of nitrous oxide.

The effect of naloxone and naltrexone on nitrous oxide withdrawal seizures was investigated in an attempt to determine if there is a link between this sign of withdrawal and the opiate mechanisms in the central nervous system. Neither antagonist modified the severity or duration of nitrous oxide withdrawal seizures. The lack of antagonist effect observed here is in accord with the observation of Goldstein and Judson who failed to observe a significant change in alcohol withdrawal seizures upon naloxone treatment. ${ }^{18}$ Thus, the nitrous oxide withdrawal seizures are probably unrelated to the endogenous opiates. These convulsions closely resemble those elicited following the withdrawal of alcohol, some general anaesthetics, ${ }^{11}$ or drugs in the sedative hypnotic class ${ }^{19}$ in dependent ani- mals. These seizures may relate to patient irritability following nitrous oxide anaesthesia.

Compulsive jumping behaviour and acute weight loss are characteristic signs of the antagonist-precipitated opiate withdrawal syndrome in mice. Therefore, these signs were evaluated in mice exposed to different concentrations of nitrous oxide following injection of naloxone in doses from 2.5 to $20 \mathrm{mg} \cdot \mathrm{kg}^{-1}$. The injection of these large doses was motivated by the observation that naloxone, while an effective antagonist of morphine, is a less effective antagonist of the endogenous opiate peptides. ${ }^{20}$ Furthermore, the action of nitrous oxide on pain and locomotor activity is antagonized by naloxone at doses considerably larger than those which inhibit morphine action. ${ }^{2,5}$. Because there is increasing evidence that naloxone may have pharmacological actions unrelated to opiate receptor blockade, ${ }^{21}$ we have also employed naltrexone in these tests. But regardless of the antagonist, its dose, or the concentration or duration of nitrous oxide exposure employed, no significant degree of jumping or weight loss was observed.

Also, other signs characteristic of opiate withdrawal in mice (sniffing, diarrhoea, increase in urination, motor activity or exploratory behaviour) were not observed in these nitrous oxide dependent rodents.

The C57BL6 mice were utilized because they were also reported to be more sensitive to the locomotor stimulation caused by morphine and nitrous oxide. ${ }^{22}$ This strain showed an unexpected decrease in severity of withdrawal convulsions when compared to Swiss White mice, but no signs of opiate-like dependence were observed.

If nitrous oxide does release endogenous opiates, then the absence of the naloxone precipitated opiate abstinence syndrome might be due to the poor specificity of naloxone in antagonizing some of these peptides, a rapid depletion of the endogenous opiate pool, failure of the endogenous opiates to reach a critical level, or their rapid metabolism. Further experiments using animals pretreated with agents inhibiting the metabolism of endogenous opiates (e.g. bacitracin or puromycin) ${ }^{23}$ may reveal opiate-like dependence on nitrous oxide. More probably, the dependence and analgesic actions of nitrous oxide are mediated by separate mechanisms. Indeed, nitrous oxide may offer an unique model for a drug which produces opiate-like analgesia unassociated with opiate dependency. 


\section{ACKNOWLEDGEMENTS}

The authors thank Maaja Sutak and Jack Schmidt for technical assistance, and Donna Bruce and the Queen's Statistical Laboratory for aid in statistical analysis.

\section{REFERENCES}

1. Berkowitz, B.A., Finck, A.D., Hynes, M.D. \& NGAI, S.H. Tolerance to nitrous oxide analgesia in rats and mice. Anesthesiology 51: 309 (1979).

2. Berkowitz, B.A., Ngai, S.H. \& FinCK, A.D. Nitrous oxide "Analgesia". Resemblance to opiate action. Science 194: 967 (1976).

3. Berkowitz, B.A., Finck, A.D. \& NGal, S.H. Nitrous oxide analgesia: Reversal by naloxone and development of tolerance. J. Pharmacol. Exp. Ther. 203: 539 (1977).

4. BLock, S.H. The grocery store high. Am. J, Psychiatry 135: 126(1978).

5. Berkowitz, B.A. \& Hynes, M.D. Nitrous oxide stimulation of locomotor activity: Evidence for an opiate-like behavioural effect. J. Pharmacol. Exp. Ther. 209: 304 (1979).

6. Chapman, C.R. \& Benedetti, C. Nitrous oxide effects on cerebral evoked potential to pain: Partial reversal with a narcotic antagonist. Anesthesiology 51: 135 (1979).

7. Koblin, D.D., Dong, D. E. \& Eger, E.I. Tolerance of mice to nitrous oxide. J. Pharmacol. Exp. Ther. 211: 317 (1979).

8. Smith, R.A., Winter, P.M., Smith, M. \& Eger, E.I. Rapidly developing tolerance to acute exposures to anesthetic agents. Anesthesiology 50: 496 (1979).

9. SMith, R.A., Winter, P.M., SMith, M. \& EgER, E.I. Tolerances and dependence on inhalational anesthetics. Anesthesiology 50: 505 (1979).

10. Harper, M.H., Winter, P.M., Johnson, B.H. Koblin, D.D. \& EGER, E.I. Withdrawal convulsions in mice following nitrous oxide. Anesth. Analg. 59: 19 (1980).
11. Smith, R.A., Winter, P.M., SMith, M. \& Eger, E.I. Convulsions in mice after anesthesia. Anesthesiology 50: 501 (1979).

12. Goldstein, D.B. An animal model for testing effects of drugs on alcohol withdrawal reactions. $J$. Pharmacol. Exp. Ther. 183: 14 (1972).

13. WEI, E. \& LOH, H. Chronic intracerebral infusion of morphine and peptides with osmotic minipumps, and the development of physical dependence. In: Kosterlitz, H.W. (ed.). Opiates and endogenous opioid peptides. Amsterdam: North Holland, 303 (1976).

14. Goldstein, D.B. Relationship of alcohol dose to intensity of withdrawal signs in mice. J. Pharmacol. Exp. Ther. 180: 203 (1972).

15. Saelens, J.K., Granat, F.R. \& Sawyer, W.K. The mouse jumping test - a simple screening method to estimate the physical dependence capacity of analgesics. Arch Int. Pharmacodyn 190: 213 (1971).

16. WAY, L.E., Loh, H.H. \& SHEN, F.H. Simultaneous quantitative assessment of morphine tolerance and physical dependence. J. Pharmacol. Exp. Ther. 167: 1 (1969).

17. Freund, J.E. Modern elementary statistics. Englewood Cliffs: Prentice-Hall, 1967.

18. Goldstein, A. \& Judson, B.A. Alcohol dependence and opiate dependence: Lack of relationship in mice. Science 172: 290 (1971).

19. Seevers, M.H. \& Tatum, A.L. Chronic experimental barbital poisoning. J. Pharmacol. Exp. Ther. 42: 217 (1931).

20. Lord, J.A.H., WATERfield, A.A., Hughes, J. \& Kosterlitz, M.W. Endogenous opioid peptides: Multiple agonists and receptors. Nature 267: 495 (1977).

21. Sawynok, J., Pinsky, C. \& LaBella, F.S. Minireview on the specificity of naloxone as an opiate antagonist. Life Sciences 25: 1621 (1979).

22. Hynes, M.D. \& Berkowitz, B.A. A genetic basis for opiate-like effects of nitrous oxide. Federation Proceedings 38, No. 3: 854 (1979).

23. VogEL, Z. \& ALTSTEIN, M. The effect of puromycin on the biological activity of leu-enkephalin. FEBS Letters 98: 44 (1979).

\section{RÉSUMÉ}

On a exposé deux souches de souris, $\mathrm{Cr} 1$ :CD-1(1CR)Br et C57B 16, à des concentrations de 50,65 et 80 pour cent de protoxyde d'azote pendant 34 ou 68 heures. L'arrèt du protoxyde d'azote a provoqué des convulsions caractéristiques identiques à celles qu-on observe lors du retrait de l'alcool chez la souris. Ces convulsions ont atteint leur paroxysme en deux ou trois minutes après l'arrêt du protoxyde et ont régressé dans les six heures suivantes. La gravité et la durée des crises étaient proportionnelles à la concentration du protoxyde d'azote ainsi qu'à la durée d'exposition. Le naloxone ou le naltrexone n'ont pas augmenté l'intensité des convulsions. Les antagonistes narcotiques n'ont pas provoqué de perte aigue de poids ni cette modification du comportement qui consiste chez l'animal physico-dépendant des opiacés à sauter. Ces résultats montrent que l'exposition chronique au protoxyde d'azote cause l'apparition d'une physico-dépendance qui s'apparente à celle de l'alcool et non à celle des opiacés. L'analgésie et la physico-dépendance produites par le protoxyde d'azote semblent être produites par des mécanismes différents. 